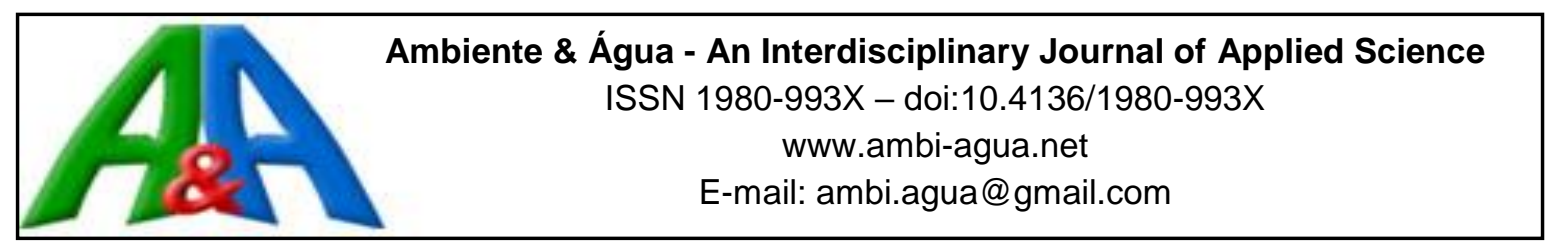

\title{
Using game theory to assess multi-company strategies in watershed management
}

\author{
doi:10.4136/ambi-agua.1697 \\ Received: 07 Jul. 2015; Accepted: 19 Apr. 2016 \\ Luke Ogilvie Thompson $^{1}$; Alexandre Bevilacqua Leoneti ${ }^{2 *}$; \\ René Bañares-Alcántara ${ }^{1}$; Eduardo Cleto Pires ${ }^{3}$ \\ ${ }^{1}$ University of Oxford, Oxford, Oxfordshire, UK \\ Engineering Science Department \\ ${ }^{2}$ Faculdade de Economia, Administração e Contabilidade de Ribeirão Preto (FEARP-USP), \\ Ribeirão Preto, SP, Brasil \\ Departamento de Administração \\ ${ }^{3}$ Escola de Engenharia de São Carlos (EESC-USP), São Carlos, SP, Brasil \\ Departamento de Engenharia \\ *Corresponding author: e-mail: ableoneti@usp.br, \\ logilviethompson@gmail.com, rene.banares@eng.ox.ac.uk, \\ ecpires@sc.usp.br
}

\begin{abstract}
The main objective of this work was to evaluate the use of game theory as a strategic tool for watershed management decision-making. An engineering problem case study was used in which three organizations compare various scenarios when deciding where to locate a polluting plant on a watershed. Six games were modeled to provide a variety of conditions that could feasibly be implemented and were simulated using software for finding Nash Equilibria solutions. The results show that game theory can provide key insights, such as the consideration of other players' strategies, and identify possible pitfalls that may occur when the companies seek only to maximize their individual profitability.
\end{abstract}

Keywords: environmental impacts, strategy, watershed.

\section{Usando a teoria dos jogos para avaliar estratégias entre empresas no gerenciamento de bacias hidrográficas}

\section{RESUMO}

O principal objetivo deste trabalho foi avaliar o uso da teoria dos jogos como uma ferramenta estratégica para a tomada de decisão no gerenciamento de bacias hidrográficas. Como estudo de caso foi utilizado um problema de engenharia em que três organizações comparam vários cenários ao escolher um local para instalar uma planta poluidora em uma bacia hidrográfica. Seis jogos foram modelados para fornecer uma variedade de condições que as empresas poderiam ser implementadas e foram simuladas usando um software para procurar Equilíbrios de Nash. Os resultados mostram que a teoria dos jogos pode fornecer informações importantes, como a consideração das estratégias dos outros agentes, e identificar 
possíveis armadilhas quando as empresas procuram apenas maximizar a sua própria rentabilidade.

Palavras-chave: bacia hidrográfica, estratégia, impactos ambientais.

\section{INTRODUCTION}

Modern companies are constantly required to consider a growing array of factors when making business decisions. The combination of highly competitive markets and global uncertainty from investors has put increasing pressure on companies to fully assess all possible actions open to them before they financially commit to any given one. Such analysis of potential business strategies can be performed in a number of ways, from traditional optimization methods to predicting market influences.

In recent years increasing importance has been given to sustainable development in its various forms, giving rise to even more factors when making decisions. Whilst multi-criteria decision making or triple-bottom-line assessments might be used to quantify the importance being given to factors such as environmental or social impact, they can suffer from a similar pitfall as other decision making techniques, namely failing to account for the influence of one company's actions on another company's decision making and, more importantly, the possible resulting ramifications upon the first company.

When companies function in close proximity, either geographically or within the same area of expertise, they will often either be drawn to working together in an effort to improve efficiency or find themselves in some form of direct or indirect competition. Such interactions may appear simplistic, as companies will logically attempt to act in their best interests. However, in some cases what initially seems to be a preferable decision for a company may result in unforeseen consequences due to the existence of other companies within the system.

The main objective of this work is to evaluate the use of Game Theory as a strategic tool for decision-making companies in the solution of problems considering the presence of more than one company and of possible conflicts. The specific objectives are to demonstrate the benefits that may be obtained from the use of Game Theory and to provide a variety of examples of how the rational behavior of firms can lead to potentially unexpected results.

The discussion is presented using an engineering case study problem in which three organizations compare various scenarios when deciding where to locate a polluting plant on a watershed. Considering the Nash Equilibrium and the Pareto efficiency concept ${ }^{1}$, the research confirms the hypothesis that two or more organizations, when acting together, might increase their overall benefits.

\section{THEORETICAL FRAMEWORK}

A large body of research considers the ways in which industrial plants can impact their environment (Hertwich et al., 1997; Sarkis, 2001; Lardon et al., 2009; Aviso, 2014). As a result, various restrictions might be placed on a watershed to ensure a healthy ecosystem, such as a limit on the level of phosphorus at various points along a stretch of a river. High levels of phosphorus cause increased eutrophication, which is a gradual process of biomass accumulation that leads to increased water pollution (Laws, 2000; Garnier et al., 2005). While

\footnotetext{
${ }^{1}$ Nash equilibrium is a solution concept of a non-cooperative game involving two or more players (Nash, 1951). The Nash equilibrium concept does not imply that the outcome from the joint strategy is the best possible. When the outcome of at least one player can improve without losses for any other player, it is said that there was a Pareto improvement. Therefore, a Pareto outcome is a situation where the joint strategy is allocated in the most efficient manner, although it may not be always possible to achieve.
} 
this is a natural process, it can be accelerated by human activities that introduce excessive nutrients into the water body (Cech, 2009). Due to the threat of high eutrophication levels, a local authority may impose restrictions on the exact concentration of phosphorus at specific points along a river, for example at densely populated locations or upstream of a larger body of water (Lira-Barragán et al., 2011a). As water-quality management and land-use planning are frequently managed by different agencies that do not constantly coordinate (Wang, 2001), integrated management and planning of water resources is an ongoing challenge. Leach and Pelkey (2001) used Exploratory Factor Analysis, that is, a multivariate statistical method often applied to identify latent patterns in available data, to search for patterns of successful partnerships in a literature review, from where four factors were identified: (i) balancing the partnership's resources with its scope of activities; (ii) employing a flexible and informal partnership structure; (iii) the dispute resolution framework; and (iv) the institutional analysis and development framework. Groot (2006) presented a framework to structure the assessment of the total value of the goods and services provided by a specific area and to analyze the costs and benefits involved in trade-offs between various land use options. Methods for identifying these impacts and trade-offs are an important instrument for watershed planners and managers.

However, many of the conventional methods used to assess strategies do not account for strategic interactions. One type of analytical technique that can be utilized by engineering firms is the application of Game Theory to enhance the decision-making process when multiple companies interact. Game theory is an analytical method that deals with situations involving two or more participants with different strategies and conflicting interests (Karlin, 1992). The theory assumes that all participants are rational, such as companies that seek to maximize their gain or "payoff" within a set of possible actions or strategies. According to Osborne and Rubinstein (1994), most strategic interaction situations can be classified as "games", within which we seek to understand the objective actions of each participant, known as a "player". Briefly, according to the principles proposed by Neuman and Morgenstern (1944), if the individuals involved in an interaction act rationally, they seek to identify alternatives that meet not only their criteria but also that meet, at least minimally, the criteria of the other participants. Therefore, the interest of game theory is evaluating the games where players make strategic decisions considering the objectives of others. When players cannot establish mutual commitments, it is said that the game is "non-cooperative", otherwise it is said to be "cooperative". Games with rewards that are inversely related, i.e., one player's gain necessarily involve a loss for one or more others, constitute the so-called "zero sum games".

There have been a few cases which may be seen as emblematic of the potential of Game Theory in the areas described above as well as in more generic engineering situations. For instance, Tecle (1992) evaluated game theory and other 14 techniques for aiding watershed resources management using a two-level process algorithm. The author concluded that game theory is one of the best methods for solving multi-criteria problems. Lou et al. (2003, p. 162) analyzed an industrial ecosystem under varying levels of production and concluded that the use of Game Theory allowed the system to reach an "economically and environmentally more desirable status". Chew et al. (2009) investigated water integration systems in Eco-Industrial Parks and identified cases where environmental benefits were lessened due to companies acting for themselves, and demonstrated how game theory can be used to suggest alternative systems that would allow for overall environmental benefits to be increased. In a subsequent piece of work, Chew et al. (2010) expanded upon their previous work by studying a larger water integration system that included interventions from authorities to help produce a more desirable outcome guided by game theory.

When looking at more general cases of water resource management, Madani (2009) applied game theory to discuss how it can be used to both identify and present resolutions to 
conflicts encountered over water resources. Leoneti et al. (2010) compared an optimized solution with a solution based on Nash equilibrium using a model to support the selection of water treatment and sewage systems of municipalities, concluding that the adoption of Nash equilibrium solutions is a viable manner to resolve the conflict between efficiency and cost in the choice of sewage treatment plants. Grimes-Casey et al. (2006, p. 1618) suggested that game theory "allows investigation of the willingness of producers and consumers to seek strategies that promote the common interest of the system while not harming their own interests" when investigating environmental alternatives to disposable bottles. Mahjouri and Ardestani (2010) proposed a game theoretic method for inter-basin water transfer management taking into account economic, equity, and environmental criteria and applying it to a large-scale inter-basin water allocation problem in Iran. Üçler et al. (2015) maximized economic benefits of land use and water quality of Namazgah reservoir, Turkey, using a biobjective optimization approach through Game Theory and fuzzy programming. Hui et al. (2015) used Nash equilibrium to analyze the decision-making process for a simple levee system when owners on both sides of the riverbank based their design-strategy decisions on economic optimization and found that each would tend to optimize their own levees using risk-based analysis, resulting in a Pareto-inefficient levee system design for the overall system. Dinar and Hogarth (2015) presents a deep literature review of other important contributions. These are just a sample from the emerging body of literature on the potential uses of game theory in engineering decision making.

\section{MATERIALS AND METHODS}

\subsection{Requirements for the model}

The research aims to simulate multi-company strategy through the use of Game Theory, focusing on the installation of multiple new industrial plants in a watershed and the impact that they have upon one another's costs. The problem is of interest due to the environmental impact of contaminants in water sources.

The model used in this research should be able to calculate a maximum discharge rate of phosphorus for a plant at any of a set of locations along a river, given the environmental regulations in place. This information is used to calculate the cost of both treatment and land purchase for situating a plant in a particular location. By performing these calculations for all of the various permutations of different locations and different industrial plants added, it would be possible to quantify the payoffs required as an input to the game theory model.

\subsection{Formulation of the model}

Akin to the work by Lovelady et al. (2009), the model in this research uses a simplified version of the Material Flow Analysis (MFA) equations proposed by El-Baz et al. (2004). The equations deal with estimating ${ }^{2}$ two separate quantities within a reach: (i) the flowrate balance (Equation 1), and (ii) the pollutant balance (Equation 2).

$$
Q_{i}=Q_{i-1}+Q_{i n R i}+Q_{\text {plant }}
$$

where:

$Q_{\mathrm{i}}$ is the flow going out of the $i^{\text {th }}$ reach;

\footnotetext{
${ }^{2}$ An estimation was deemed justifiable as the model was intended to produce results in order to apply game theory to the case. In essence, the results themselves were not required to be necessarily accurate but simply realistic.
} 
$Q_{\mathrm{i}-1}$ the flow going into the $i^{\text {th }}$ reach coming from the $i-1^{\text {th }}$ reach;

$Q_{i n R i}$ is the flow from/to the tributaries into the $i^{\text {th }}$ reach, all in $\mathrm{m}^{3} / \mathrm{s}$. It should be noted that this last flow could be either positive or negative; and

$Q_{\text {plant }}$ is the total discharge from the chemical plant being added to the reach, also in $\mathrm{m}^{3} / \mathrm{s}$; this value would be zero if a chemical plant is not added to the reach.

$$
Q_{i} \cdot C_{P, i}=Q_{i-1} \cdot C_{P, i-1}+Q_{i n R i} \cdot C_{P, i n R i}-k \cdot\left(C_{P, i}\right)^{\sigma} \cdot V_{i}+x \cdot Q_{\text {plant }} \cdot C_{P, p l a n t}
$$

where:

$k$ is the kinetic constant for phosphorus of $9.0419 \times 10^{-6} / \mathrm{s}$ obtained experimentally by Lira-Barragán et al. (2011a);

$\sigma$ is the order of reaction;

$V_{\mathrm{i}}$ is the volume of the reach in $\mathrm{m}^{3}$;

$C_{P, \text { inRi }}$ is the component concentration in the bulk flow into or out of the $i^{\text {th }}$ reach in ppm;

$x$ is the fraction of waste that leaves the chemical plant untreated; and

$C_{P \text {,plant }}$ is the component concentration of untreated waste from the chemical plant into the $i^{\text {th }}$ reach in ppm. As before, if a chemical plant is not being added to the reach in question, then the last term is zero.

\subsection{Case Study: Adding phosphorus polluting plants to the watershed including Lake Manzala while maintaining environmentally acceptable levels of pollutant}

The case presented in this section has been adapted from the works of Lovelady et al. (2009) and Lira-Barragan et al. (2011a; 2011b), both made for the case of a single chemical plant. Here, the case includes three major drains combined to transport water from Cairo to Lake Manzala, in Egypt: the Qalyoubia Drain, the Bilbeis Drain and the Bahr El-Baqar Drain. Data from multiple sources was pieced together, including data regarding volumetric flowrate collected by Stahl et al. (2009) and upstream phosphorus concentration calculated by Lovelady et al. (2009), to provide the initial conditions at various points along the main reaches of the watershed (Figure 1). Table 1 shows the estimations collected for each position of the reaches shown in Figure 1.

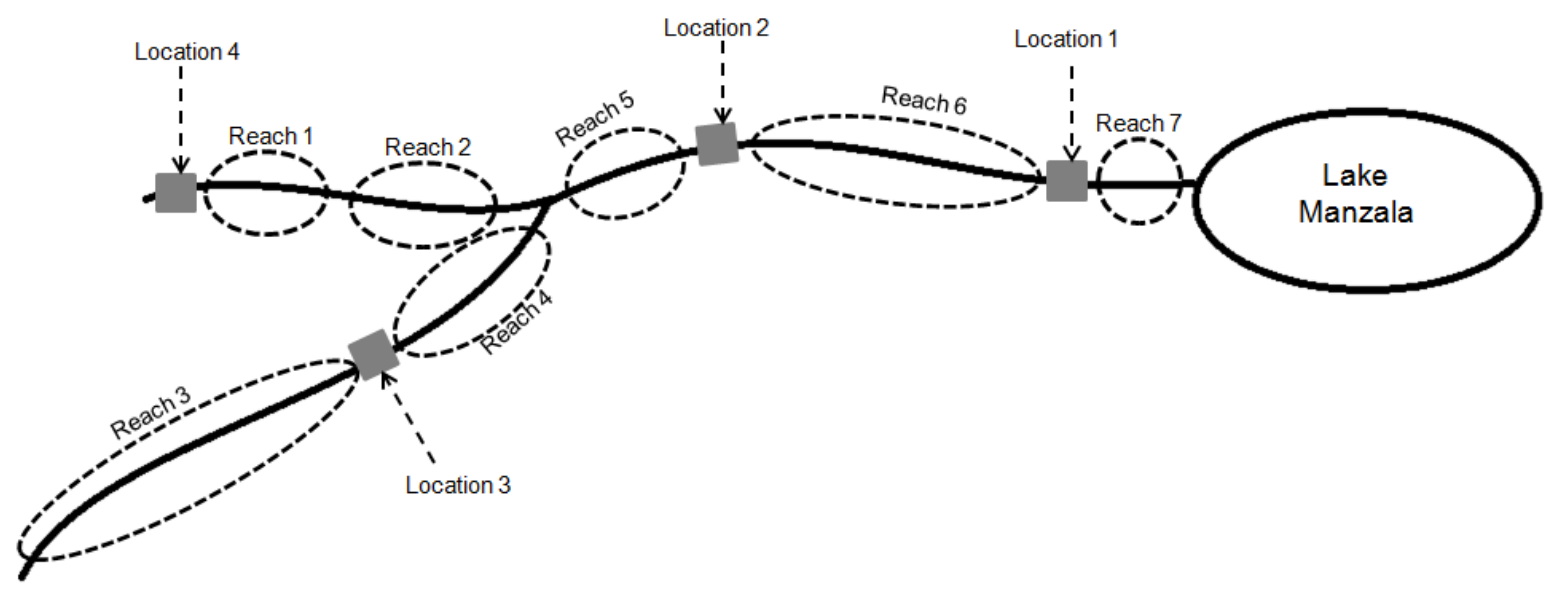

Figure 1. Diagram showing the proposed plant locations and designation of reaches. 
Table 1. Original data.

\begin{tabular}{ccc}
\hline $\begin{array}{c}\text { Position along river } \\
\text { (beginning of reach No.) }\end{array}$ & $\begin{array}{c}\text { Volumetric } \\
\text { Flowrate }\left(\mathrm{m}^{3} \mathrm{~s}^{-1}\right)\end{array}$ & $\begin{array}{c}\text { Phosphorus } \\
\text { Concentration } \\
(\mathrm{ppm})\end{array}$ \\
\hline 1 & $20^{* * *}$ & $1.300^{* * *}$ \\
2 & $14^{*}$ & $1.425^{* *}$ \\
3 & $21^{*}$ & $1.200^{* *}$ \\
4 & $32^{*}$ & $1.420^{* * *}$ \\
5 & $68^{*}$ & $1.325^{* *}$ \\
6 & $65^{*}$ & $1.825^{* *}$ \\
7 & $67^{*}$ & $1.200^{* *}$ \\
\hline
\end{tabular}

Source: * (Stahl et al., 2009); ** (Lovelady et al., 2009); *** estimated to fit the model.

In this case study, three companies each add one fertilizer producing plant in one of four locations along the watershed (Figure 1) and they are required to treat enough of their effluent to ensure that the regulation levels of phosphorus are not exceeded. It was assumed that fully untreated effluent from a fertilizer plant would be at 12.5 parts per million (ppm) of phosphorus and have a flowrate of 2 cubic meters per second (Lovelady et al., 2009). The phosphorus limits set along the watershed were the following: the flow into Lake Manzala must not exceed $1.3 \mathrm{ppm}$, the pollution at the beginning of Reach 2 (Figure 1) should not go above 2 ppm due to water being withdrawn for human consumption, and at no point in the river should the phosphorus level reach above 3 ppm (Lira-Barragán et al., 2011b).

Once this data was collected, two models based on Equations 1 and 2 were coded in MATLAB and were used to estimate the progression of phosphorus along the river. The first MATLAB code was used to determine the lump sum inputs required to replicate the phosphorus concentrations shown in Table 1, considering the values of $\$ 10, \$ 17, \$ 19.5$ and $\$ 18$ million USD for Locations 1 to 4 (Lira-Barragán et al., 2011a). Then, the second MATLAB code was formulated to allow for the addition of the new chemical plants to the watershed and to find, to the nearest percentage, the amount of the effluent that would need to be treated by each plant. This process was done sequentially so the code only needed to find the percent of treatment required for one plant at a time. The treatment cost used was $\$ 21$ per $\mathrm{kg}$ of phosphorus removed (Lovelady et al., 2009), with an annual plant operation time of 8000 hours per year (Lira-Barragán, 2011b). Once the treatment costs were calculated, they were combined with the cost of the land to find the overall cost for placing the plant in that location. The basic land costs, annualized over the functional life span of the plant, are shown in the second column of Table 2.

Table 2. Land costs for the locations considered in the case study.

\begin{tabular}{cc}
\hline Location & $\begin{array}{c}\text { Annualized Land Cost } \\
\text { (\$ million USD) }\end{array}$ \\
\hline 1 & $10^{*}$ \\
2 & $17^{*}$ \\
3 & $19.5^{* *}$ \\
4 & $18^{*}$ \\
\hline
\end{tabular}

Source: * Lira-Barragán et al. (2011a); ** adapted from Lira- Barragán et al. (2011a) to provide a more interesting discussion on game theory. 
As a final step, the costs generated for each of the four strategies were deducted from $\$ 100$ million USD so as to produce payoffs where a higher value was preferable. Nash equilibria were identified by GAMBIT, a software developed by McKelvey et al. (2010) for finding Nash equilibria in extended or strategical games (Nash, 1951). It is important to note that for the volume of the reaches used, it was necessary to double the $k$ value stated in Section 3.2 to achieve a rate of degradation that replicates the findings from Lovelady et al. (2009).

\subsection{Summary of games used}

At this point multiple games were implemented in order to aid the decision-making process through the evaluation of different possible scenarios. In the first game, called "First come priority", it was assumed that the first plants built in a specified location are given the benefit of not having to increase their treatment costs as other plants are built along the watershed. As a result, when a plant is built it is able to pollute as much as is allowed by environmental regulations and its treatment costs will not be affected by the addition of subsequent plants. In the second game, the "Increased land costs" game, the same situation as in Game 1 was assumed for the first plant; however, in this case plants were penalized for building in the same location by a rising land cost of 50\% every time a plant is built in the same location. In the third game, "Matching treatment costs,' if a plant is built in the same location as another plant, the first plant is then required to increase its treatment costs such that both plants have the same treatment costs. The fourth game merges Games 2 and 3 to examine the combined impact of both treatment cost matching and increasing land cost when sharing the same location. In the fifth game, which is called "Proximity of subsequent plants increasing costs", the proximity of subsequent plants caused a variable increase in the treatment costs of existing plants. The first plant would have to increase its treatment by $15 \%$ if a subsequent plant is placed in the same location, by $10 \%$ if the subsequent plant is placed in any upstream adjacent location, and by $5 \%$ if the new plant is placed further away. For the second plant, these values were $8 \%, 5 \%$ and $2 \%$ respectively. It was decided that the second plant would be penalized less as it was observed that the first plant had far lower treatment costs due to being built earlier when the watershed was less saturated with phosphorus. As for the individual location proximities with respect to one another, Location 2 is adjacent to all the other locations and no other locations are adjacent to each other. A caveat to this is that, if a plant was built in the same location as a previous plant, this could not cause the existing plant to have a higher treatment cost that the new plant. The final game investigated the combination of the proximity influence from Game 5 and the increasing land cost from Game 2. These games were considered to provide an interesting variety of conditions that could feasibly be implemented as policy in the watershed system. Whilst other multiple small permutations were considered, the games listed proved to be the most interesting.

\section{RESULTS AND DISCUSSION}

\subsection{Game 1: First come priority}

In this highly simplistic case, the Nash equilibrium solution for this game is L1, L1, L1 (L1, L1 and L1 are the location choices among the locations L1, L2, L3 or L4 for companies one, three and two respectively ${ }^{3}$ ), highlighted in Figure 2 . It can easily be identified that the first company to place a plant (payoff values in the left marginal rows 1, 2, 3 and 4) has the best response, with a payoff of 84.0, by locating their factory in Location 1, as all the other strategies are strictly dominated by this strategy ( 84.0 versus $82.4,80.5$, and 77.3$)$. A strategy

\footnotetext{
${ }^{3}$ It is worth noting that GAMBIT standard output presents the payoff of player one in the first cell, the payoff of player three in the second cell and payoff of player two in the last cell.
} 
is said to be strictly dominated when it leads to worse payoffs than any other strategy independent of all the other players' chosen strategies. The second company (payoff values in the top columns 1, 2, 3 and 4) should also build in Location 1 as this provides the highest possible payoff for them, which is 76.4, given the first company's likely action. Therefore, Location 1 is also the best response for player two as all other strategies are strictly dominated. Likewise, the third company (payoff values in lines 1, 2, 3 and 4 within each left marginal row) should also build in the same location as this also provides the highest payoff for them, which is 76.5. As a result, if the companies were to work together to obtain the highest combined payoff given by the Nash Equilibrium solution, i.e., the lowest total cost, they would all build at Location 1. This outcome of L1, L1, and L1 is also the Pareto optimal solution as while both the second and third plants could increase their payoffs, they could not do so without reducing the payoff of the first plant.

\begin{tabular}{|c|c|c|c|c|c|c|c|c|c|c|c|c|c|c|}
\hline 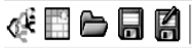 & \multirow{6}{*}{$\begin{array}{c}=0 \\
1\end{array}$} & $8 \mid 00$ & 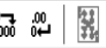 & 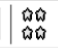 & & & & & & & & & & \\
\hline \multirow{17}{*}{$\begin{array}{l}8 \text { \& } 8 \text { Player } 1 \\
8 \text { \& } 8 \text { Player } 2 \\
8 \text { \& Player } 3\end{array}$} & & & \multicolumn{3}{|c|}{1} & \multicolumn{3}{|c|}{2} & \multicolumn{3}{|c|}{3} & \multicolumn{3}{|c|}{4} \\
\hline & & 1 & 84.0 & 76.5 & 76.4 & 84.0 & $\begin{array}{l}76.5 \\
\end{array}$ & 699.5 & $\begin{array}{l}80.3 \\
\end{array}$ & 76.5 & $\begin{array}{c}66.9 \\
\end{array}$ & 84.0 & 76.5 & $\begin{array}{c}68.4 \\
\end{array}$ \\
\hline & & 2 & 84.0 & 69.7 & 76.4 & 84.0 & 69.7 & 69.5 & 84.0 & 69.7 & 66.7 & 84.0 & 69.7 & 68.4 \\
\hline & & 3 & 84.0 & 67.0 & 76.4 & 84.0 & 67.0 & 69.5 & 84.0 & 67.0 & 66.9 & 84.0 & 67.0 & 68.4 \\
\hline & & 4 & 84.0 & 68.7 & 76.4 & 84.0 & 68.7 & 69.5 & 84.0 & 68.7 & 66.9 & 84.0 & 68.7 & 59.4 \\
\hline & & 1 & 82.4 & 76.4 & 76.5 & 82.4 & 76.4 & 69.5 & 82.4 & 76.4 & 66.9 & 82.4 & 76.4 & 68.5 \\
\hline & 2 & 2 & 82.4 & 69.4 & 76.4 & 82.4 & 69.4 & 69.4 & 82.4 & 69.4 & 66.7 & 82.4 & 69.4 & 68.2 \\
\hline & 2 & 3 & 82.4 & 66.7 & 76.4 & 82.4 & 66.7 & 69.4 & 82.4 & 66.7 & 66.6 & 82.4 & 66.7 & 68.1 \\
\hline & & 4 & 82.4 & 68.1 & 76.4 & 82.4 & 68.1 & 69.4 & 82.4 & 68.1 & 66.7 & 82.4 & 68.1 & 59.1 \\
\hline & & 1 & 80.5 & 78.7 & 76.5 & 80.5 & 78.7 & 69.5 & 80.5 & 78.7 & 66.7 & 80.5 & 78.7 & 68.4 \\
\hline & 3 & 2 & 80.5 & 73.3 & 76.4 & 80.5 & $\begin{array}{l}73.3 \\
\end{array}$ & 69.4 & 80.5 & 73.3 & 66.4 & 80.5 & 73.3 & 67.8 \\
\hline & 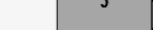 & 3 & 80.5 & 72.3 & 76.4 & 80.5 & 72.3 & 69.4 & 80.5 & 72.3 & 66.4 & 80.5 & 62.6 & 67.8 \\
\hline & & 4 & 80.5 & 77.3 & 76.5 & 80.5 & 77.3 & 69.5 & 80.5 & 77.3 & 66.7 & 80.5 & 77.3 & 58.6 \\
\hline & & 1 & 77.3 & 82.0 & 76.4 & 77.3 & 82.0 & 69.4 & 77.3 & 82.0 & 66.7 & 77.3 & 82.0 & 58.8 \\
\hline & & 2 & 77.3 & 78.8 & 76.4 & 77.3 & 78.8 & 69.4 & 77.3 & 78.8 & 66.6 & 77.3 & 78.8 & 58.5 \\
\hline & 4 & 3 & 77.3 & 80.5 & 76.5 & 77.3 & 80.5 & 69.5 & 77.3 & 80.5 & 66.7 & 77.3 & 80.5 & 58.6 \\
\hline & & 4 & 77.3 & 69.3 & 81.5 & 77.3 & 69.3 & 78.0 & 77.3 & 69.3 & 79.4 & 77.3 & 60.3 & 46.8 \\
\hline
\end{tabular}

Figure 2. Screen of GAMBIT with the payoffs from Game 1 with Nash equilibrium in gray.

At this point, it should be mentioned that all the games in the study resulted in Pareto optimal solutions. This fact does not provide any insight, but merely states that companies will always achieve their maximum payoff.

\subsection{Game 2: Increased land costs}

As the payoffs for the first plant are unchanged, it is expected that the best response for this company will still be to build at Location 1 . Also, for the third plant, it is still the best response to build at the same location because, although the cost increases, it does not increase enough to make another location more profitable. However, due to the increasing cost, it should now be more profitable for the second company to install its plant at Location 2 , as the sharp rise in land cost has now made the cost of building in the same location as the other two plants too expensive. As such, the Nash Equilibrium of the game is the situation of plants being built at L1, L1, L2 (first, third and second company). Again the non-cooperative solution is a Pareto optimal solution as both companies 2 and 3 could achieve a higher payoff, but only at an increased cost for the first company.

\subsection{Game 3: Matching treatment cost}

In this case, the non-cooperative solution to the game is for the first company to build in Location 2 while the second and third plants will be built in Location 1, i.e., L2, L1, L1. This is interesting as, while the majority of the payoffs for the first company building in Location 1 are higher than those for Location 2, if the first company were to build its plant in Location 1 the best responses from the other two companies would be to also build in Location 1, driving up the costs and thus lowering the payoff for the first company. Therefore, the Nash 
equilibrium is also Pareto optimal, since both companies two and three could achieve a higher payoff, but only at the cost of company one. Figure 3 presents the Nash equilibrium to the game.

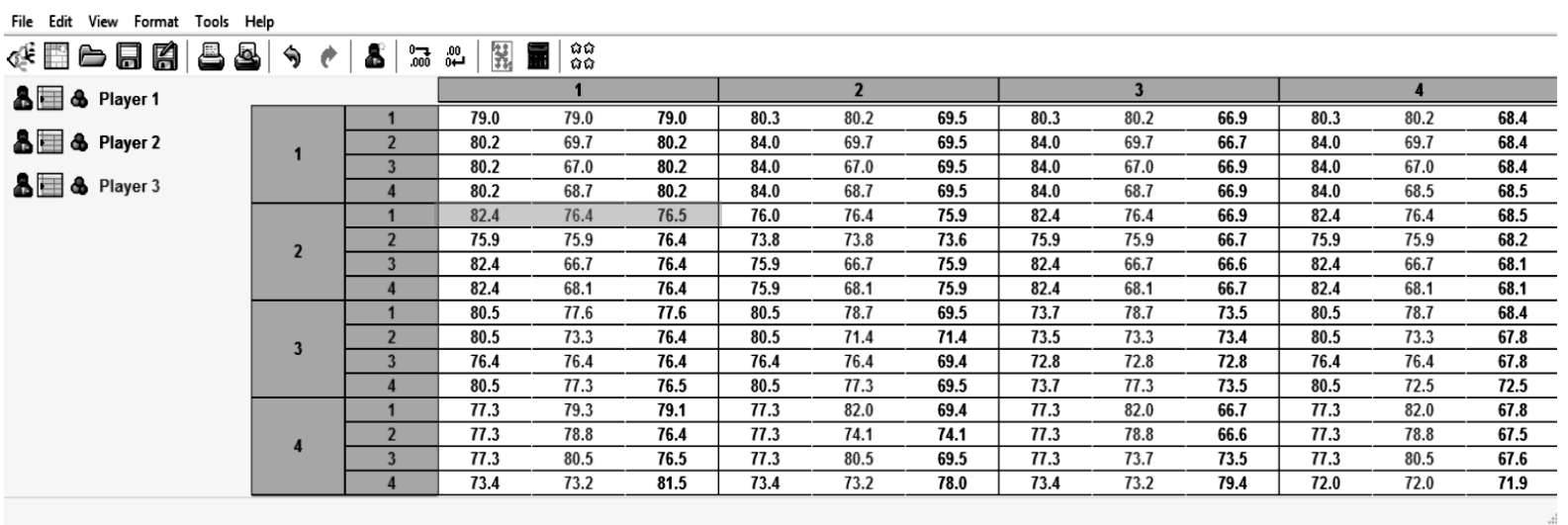

Figure 3. Screen of GAMBIT with the payoffs from Game 3 with Nash equilibrium in gray.

In fact, recalling that GAMBIT presents the payoff of the first company in the first cell, the payoff of the third company in the second cell and payoff of the second company in the last cell, it can be deduced from Figure 3 that there is no possibility of increasing the payoff for companies two (columns 1, 2, 3 or 4 crossing the marginal row 2) and three (row 1, 2, 3 or 4 inside the marginal row 2) when company one chooses Location 2 (the marginal row 2).

\subsection{Game 4: Combination of Games 2 and 3}

Similar to Game 3, the Nash equilibrium of this game is L2, L1, and L1.

\subsection{Game 5: Proximity of subsequent plants increasing costs}

The outcome of this game is similar to the previous two in that the first company is deterred from building in Location 1 because the best responses of the other two companies would lead to a lower payoff for the first company. However, the payoffs for situations L1, L1, L1 and L2, L1, L1 are exactly the same for the first plant to be built. As all the other payoffs for the first plant being built in Location 1 are higher than for Location 2, it would be advisable for the first plant to build in Location 1 in case one of the other companies do not act rationally or lacks information and therefore increase the first company's payoff accidentally while reducing their own. As such, it turns out that the non-cooperative solution of this game is L1, L1, and L1.

\subsection{Game 6: Combination of Games 2 and 5}

Finally, this last game shares the same explanation as Game 5 for placing the first plant at Location 1. However, in a similar fashion to Game 2, the third plant to be installed would be best placed at Location 2 due to the second plant having, again, a best response in Location 1. This means that the non-cooperative solution is L1, L2, and L1.

\subsection{Conclusions from the results}

The results of the games show some clear situations in which rational decision making can lead to a better outcome for a company. For example, in Game 3 the temptation for the first company might be to implement the strategy that provides them with the largest possible payoff, in this case opting for Location 1. However, by carefully considering the likely behavior of the other companies, it becomes clear that the first company should opt for a different location to avoid a lower payoff due to other companies maximizing their payoffs. This illustrates the ability of game theory to ensure that companies do not get misled by 
attractive possibilities in isolation whilst overlooking the influence other companies could have on the eventual payoff. Consequently, it is suggested that the adoption of a game theory approach can enhance the process of managing and planning watersheds, as suggested by Tecle (1992), Wang (2001) and Leoneti et al. (2010).

An interesting aspect of game theory that the games discussed above did not investigate was that of players not having complete or accurate information. This was touched upon in the results from Game 5, where it was mentioned that although the first company would most likely obtain the same payoff whether they built at Location 1 or 2 , the rational choice would be to build in Location 1 in the event that the other players did not act as expected. It should be noted that in all the games if any company had incomplete/incorrect knowledge of all the payoffs then it could drastically alter their likely strategies. While the games investigated did not specifically account for imperfect knowledge amongst the players as such, it is an interesting coincidence that Games 5 and 6 presented situations where it could easily have a correspondent effect.

Finally, it is important to stress that likewise other studies in literature (Lou et al.; 2003; Chew et al., 2009; Aviso, 2014) it was found that industrial allocation can be better performed when considering other aspects of the problem beyond economic aspects and that this assessment could be performed with the aid of a game theoretical approach. In accordance with Madani (2009) and Leoneti et al. (2010), benefits include conflict resolution.

\section{CONCLUSIONS}

Two particular conclusions could be considered as the most important. First, game theory can be used to provide key insights for business decision-making processes, as it can identify possible pitfalls when seeking to maximize profitability. This is key, as it underscores the importance for companies to be aware of the implications of the strategies of possible competitors and to act accordingly. It should be noted that game theory can also be useful when the competitors' strategies and associated payoffs are not fully known. Second, game theory can analyze a variety of situations simultaneously and in this way help inform decision making for both multiple companies as well as for single companies performing multiple actions. This is important, as it has been shown that game theory can be used to avoid a company from inadvertently increasing its own costs by not considering possible future actions. Game theory is by no means the only form of forward-planning decision making; however, the results have shown its potential when other competitors are involved.

This research also contributes to the discussion on the use of game theory in an engineering context. First, this study takes an existing published work, which adds a single chemical plant to a watershed, and extends it by increasing the number of plants and analyzing the results by applying game theory to the system. Second, by demonstrating a variety of games based on the case study, the paper contributes to the discussion on the use of game theory in engineering situations. By identifying multiple examples where game theory gives a useful addition to the decision-making process, this research strengthens the claim that game theory is a potent analytical tool in engineering decision scenarios. This research thus builds upon previous uses of game theory in engineering and offers points of departure for further discussion on the topic.

Perhaps the most significant limitation to the project was the influence of some parameter values, such as land prices on the payoffs and subsequently on the outcome of the games. Some of them are important, e.g. the land costs made up a sizeable amount of the overall costs for each plant and hence the land cost value assigned to each location would have a major influence in deciding whether it was generally a desirable location or not. While this problem was somewhat alleviated by adapting the values suggested by previous literature, 
the results of the game theory were still heavily influence by the values chosen. However, this limitation is not sufficient to negate the overall demonstration of the usefulness of game theory as a decision-making tool for watershed management.

\section{ACKNOWLEDGMENTS}

The authors thank FAPESP for Visiting Professor Support (2013/06807-3) and for the Ph.D. Scholarship (2009/07598-3). The authors also acknowledge the helpful comments of the anonymous referees.

\section{REFERENCES}

AVISO, K. B. Design of robust water exchange networks for eco-industrial symbiosis. Process Safety and Environmental Protection, v. 92, n. 2, p. 160-170, 2014. http://dx.doi.org/10.1016/j.psep.2012.12.001

$\mathrm{CECH}, \mathrm{T}$. V. Principles of water resources: history, development, management, and policy. New York: John Wiley \& Sons, 2009.

CHEW, I. M. L.; TAN, R. R.; FOO, D. C. Y.; CHIU, A. S. F. Game theory approach to the analysis of inter-plant water integration in an eco-industrial park. Journal of Cleaner Production, v. 17, p. 1611 - 1619, 2009. http://dx.doi.org/10.1016/j.jclepro.2009.08.005

CHEW, I. M. L.; THILLAIVARRNA, S. L.; TAN, R. R.; FOO, D. C. Y. Analysis of interplant water integration with indirect integration schemes through game theory approach: Pareto optimal solution with interventions. Clean Technologies and Environmental Policy, v. 13, p. 49 - 62, 2010. http://dx.dio.org/10.1007/s10098-010-0280-x

DINAR, A.; HOGARTH, M. Game theory and water resources critical review of its contributions, progress and remaining challenges. Foundations and Trends in Microeconomics, v. 11, n. 1-2, p. 1-139, 2015. http://dx.doi.org/10.1561/0700000066

EL-BAZ, A. A.; KAMAL, M.; EWIDA, T.; SHOUMAN, M. A.; EL-HALWAGI, M. M. Material flow analysis and integration of watersheds and drainage systems: 1. Simulation and application to ammonium management in Bahr El-Baqar drainage system. Clean Technologies and Environmetal Policy, v. 7, p. 51 - 61, 2004. http://dx.doi.org/10.1007/s10098-004-0258-7

GARNIER, J.; NEMERY, J.; BILLEN, G. Nutrient dynamics and control of eutrophication in the Marne River system: Modelling the role of exchangeable phosphorous. Journal of Hydrology, v. 204, n. 1, p. 397-412, 2005.

http://dx.doi.org/10.1016/j.jhydrol.2004.07.040

GRIMES-CASEY, H. G.; SEAGER, T. P.; THEIS, T. L.; POWERS, S. E. A game theory framework for cooperative management of refillable and disposable bottle lifecycles. Journal of Cleaner Production, n. 15, p. 1618-1627, 2006. http://dx.doi.org/10.1016/j.jclepro.2006.08.007

GROOT, R. Function-analysis and valuation as a tool to assess land use conflicts in planning for sustainable, multi-functional landscapes. Landscape and Urban Planning, v. 75, p. 175-186, 2006. http://dx.doi.org/10.1016/j.landurbplan.2005.02.016 
HERTWICH, E. G.; PEASE, W. S.; KOSHLAND, C. P. Evaluating the environmental impact of products and production processes: a comparison of six methods. Science of the Total Environment, v. 196, n. 1, p. 13 - 29, 1997. http://dx.doi.org/10.1016/S00489697(96)05344-2

HUI, R.; MADANI, K.; LUND, J. R. Risk-based levee system design: Rational vs. optimal. In: WORLD ENVIRONMENTAL AND WATER RESOURCES CONGRESS, 2015. Proceedings... [S.1.]: American Society of Civil Engineers, 2015. p. 2208-2217. http://dx.doi.org/10.1061/9780784479162.217

KARLIN, S. Mathematical methods and theory in games, programming, and economics and matrix games, programming, and mathematical economics. Mineola: Dover Pubns, 1992.

LARDON, L.; HÉlIAS, A.; SIALVE, B.; STEYER, J.; BERNARD, O. Life-cycle assessment of biodiesel production from microalgae. Environmental Science and Technology, v. 43, n. 17, p. 6475-6481, 2009. http://dx.doi.org/10.1021/es900705j

LAWS, E. J. Aquatic pollution: an introductory text. New York: John Wiley \& Sons, 2000.

LEACH, W.; PELKEY, N. Making watershed partnerships work: a review of the empirical literature. Journal of Water Resources Planning and Management, v. 127, n. 6, p. 378-385, 2001. http://dx.doi.org/10.1061/(ASCE)0733-9496(2001)127:6(378)

LEONETI, A. B.; OLIVEIRA, S. V. W. B.; OLIVEIRA, M. M. B. The Nash equilibrium as a solution to the conflict between efficiency and cost in the choice of systems for sanitary sewage treatment using a decision making model. Engenharia Sanitária e Ambiental, v. 15, n.1 p. 53-64, 2010. http://dx.doi.org/10.1590/S1413-41522010000100007

LIRA-BARRAGÁN, L. F.; PONCE-ORTEGA， J. M.; SERNA-GONZÁlEZ， M.; ELHALWAGI, M. M. An MINLP Model for the Optimal Location of a New Industrial Plant with Simultaneous Consideration of Economic and Environmental Criteria. Industrial and Engineering Chemistry Research, v. 50, p. 953-964, 2011a. http://dx.doi.org/10.1021/ie101897z

LIRA-BARRAGÁN，L. F.; PONCE-ORTEGA，J. M.; SERNA-GONZÁLEZ，M.; ELHALWAGI, M. M. Synthesis of water networks considering the sustainability of the surrounding watershed. Computers \& Chemical Engineering, v. 35, p. 2873-2852, 2011b. http://dx.doi.org/10.1016/j.compchemeng.2011.03.021

LOU, H. H.; KULKARNI, M. A.; SINGH, A.; HUANG, Y. L. A game theory based approach for emergy analysis of industrial ecosystem under uncertainty. Clean Technologies and Environmental Policy, v. 6, n. 3, p. 156-161, 2003. http://dx.doi.org/10.1007/s10098003-0235-6

LOVELADY, E.; EL-BAZ, A. A.; EL-MONAYERI, D.; EL-HALWAGI, M. M. Reverse problem formulation for integrating process discharges with watersheds and drainage systems: managing phosphorous in Lake Manzala. Journal of Industrial Ecology, v. 13, n. 6, p. 914-927, 2009. http://dx.doi.org/10.1111/j.1530-9290.2009.00179.x

MADANI, K. Game theory and water resources. Journal of Hydrology, v. 381, p. 225-238, 2009. http://dx.doi.org/10.1016/j.jhydrol.2009.11.045 
MCKELVEY, R. D.; MCLENNAN, A. M.; TUROCY, T. L. Gambit: software tools for game theory. Version 0.2010.09.01. 2010. Available in: http://www.gambit-project.org. Access: may 2016.

MAHJOURI, N.; ARDESTANI, M. A game theoretic approach for interbasin water resources allocation considering the water quality issues. Environmental Monitoring and Assessment, v. 167, n. 1-4, p. 527-544, 2010. http://dx.doi.org/10.1007/s10661-0091070-y

NASH, J. Non-cooperative games. Annals of Mathematics, v. 54, p. 286-295, 1951. http://dx.doi.org/10.2307/1969529

NEUMAN, J. V.; MORGENSTERN, O. Theory of games and economic behavior. Princeton: Princeton University Press, 1944.

OSBORNE, M. J.; RUBINSTEIN, A. A course in game theory. Cambridge: MIT Press, 1994.

SARKIS, J. Manufacturing's role in corporate environmental sustainability - Concerns for the new millennium. International Journal of Operations and Production Management, v. 21, n. 5, p. 666-686, 2001. http://dx.doi.org/10.1108/01443570110390390

STAHL, R.; RAMADAN, A. B.; PIMPL, M. Bahr El-Baqar drain system, Egypt environmental studies on water quality ; Part 1: Bilbeis drain, Bahr El-Baqar drain. Karlsruhe: Institut für Technische Chemie, 2009.

TECLE, A. Selecting a multicriterion decision making technique for watershed resources management. JAWRA Journal of the American Water Resources Association, v. 28, n. 1, p. 129-140, 1992.

ÜÇLER, N.; ENGIN, G. O.; KÖÇKEN, H. G.; ÖNCEL, M. S. Game theory and fuzzy programming approaches for bi-objective optimization of reservoir watershed management: a case study in Namazgah reservoir. Environmental Science and Pollution Research, v. 22, n. 9, p. 6546-6558, 2015. http://dx.doi.org/10.1007/s11356015-4181-8

WANG, X. Integrating water-quality management and land-use planning in a watershed context. Journal of Environmental Management, v. 61, p. 25-36, 2001. http://dx.doi.org/10.1006/jema.2000.0395 